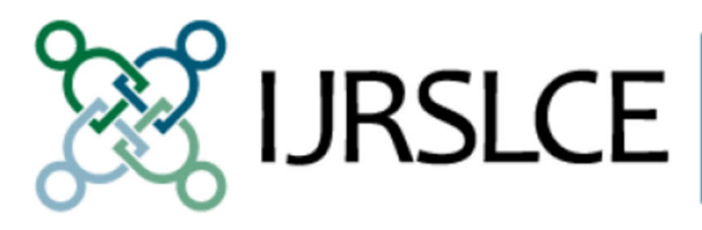

International Journal

for Research on

Service-Learning \&

Community Engagement

\title{
Book Review: Where's the Wisdom in Service-Learning?
}

\section{Christopher Adam Ray}

This article was originally published at:

https://journals.sfu.ca/iarslce/index.php/journal/article/view/303/195

Recommended Citation

Ray, C. A. (2017). Book Review: Where's the wisdom in service-learning? International Journal of Research on Service-Learning and Community Engagement, 5(1), 185-187. 


\title{
Book Review: Where's the Wisdom in Service-Learning?
}

\author{
Christopher Adam Ray \\ Western Carolina University
}

\begin{abstract}
Reviewed in this article: Where's the Wisdom in Service-Learning? Edited by Robert Shumer. Information Age Publishing, Charlotte, NC. April 1, 2017. ISBN: 978-1681238647. 204 pages.
\end{abstract}

Edited by Robert Shumer from the University of Minnesota, Where's the Wisdom in Service-Learning? highlights the experiences, insights, and opinions of a diverse group of authors and practitioner-scholars linked historically by service-learning. Rather than focusing solely on the beginnings or roots of servicelearning - defined as "the accomplishment of tasks that meet genuine human needs in combination with conscious educational growth" (Stanton, Giles, \& Cruz, 1999, p. 2) -this volume expounds upon the concept by including not only the unique wisdom of its authors, but also their equally important recommendations for future efforts aligned with service-learning. Comprising 12 chapters, the work intricately and effectively weaves diverse personal stories and experiences with foundational knowledge related to service-learning.

Chapter 1 sets the stage by providing a brief framework for the concept of service-learning, tracking its lineage by means of a thematic timeline and emphasizing that service-learning is "rooted in three concepts: the common good, civil society, and learning by doing" (Shumer, 2017, p. 1). In addition to these concepts, Shumer, Stanton, and Giles (2017) address the transformative nature of service-learning by describing its evolution over the past four decades. They also address the combined impact that service-learning has had within the realms of public education, higher education, research, and the publicservice sector within each decade. Finally, the chapter describes the global progression of service-learning while leaving readers with the charge of keeping the common good, civil society, and learning by doing at the core of service-learning into the $21^{\text {st }}$ century in their efforts to combat critical societal issues.

\section{Reflective Practice and the Authors' Core Experiences}

The remaining chapters within the volume present information within an easily accessible format that includes various authors' personal reflections on their involvement in service-learning, followed by a section devoted to their recommendations to the field. Each chapter is not only brilliantly descriptive, but provides unique perspectives on the evolution and impact of service-learning. From Jane Szutu Permaul's reflections on helping military veterans to reintegrate into civilian life in Chapter 6 to Terry Pickeral's discussion of integrating service-learning as a core concept within the educational curriculum of middle school students in Chapter 8, each reflection is unique and powerful.

One of the more common themes addressed within each of the chapters relates to the authors becoming involved with community engagement initiatives at a relatively young age, but none of them links his or her involvement in such activities with service-learning as defined today. Yet, they observe that their community engagement activities of various forms likely served as critical foundations for not only their unique passion within service-learning, but also their future occupations. For example, in 
Chapter 5, Timothy Stanton reflects on his lifelong involvement with service-learning, which began with his participation in a civil rights demonstration and which challenged his understanding of discrimination as being isolated to the South, revealing to him the prevalence of such inequities across the entire United States. This ignited in him a passion for raising the consciousness of his peers and community members about the discrimination occurring in their own backyard. Moreover, this event sparked what would become a 45-year career focused on service-learning.

Within this same vein, James Kielsmeier, in Chapter 7, shares his personal insight on the impact of service-learning and involvement within his life, which differs from his co-authors. That is, his personal reflections are framed as a proposal related to restoring the funding and support for the Learn and Serve America (LSA) program. In addition to providing a descriptive proposition related to refunding LSA, Kielsmeier details the military and teaching experiences that proved to be precursors of his servicelearning work, as well as his governmental ties related to the National and Community Service Act. The unique approach taken by Kielsmeier in this chapter not only helps to answer the question of where the wisdom in service-learning is, but also serves as a proactive stance for service-learning in the future.

\section{Future Practice and Implications}

After Chapter 1, each of the subsequent chapters includes the respective author's recommendations for future practice, in some cases making reference to specific service-learning-driven initiatives that validate the field as a whole. In Chapter 2, John Duley writes about his utilization of the Student Tutorial Education Project to showcase the longitudinal impact that service-learning can have. By referencing Russell Edgerton's (1997) "pedagogies of engagement” and Lee Shulman's (2002) "table of learnings," Duley reinforces the claim that service-learning is truly transformative work and also charges the next generation of practitioners to link future practices with scholarly work centering on engagement practices.

Whereas all of the authors within Where's the Wisdom in Service-Learning? address the concept of best practices, they each do so in a different but equally effective way. As mentioned earlier, the text clearly speaks to future practitioners and emphasizes the importance of connecting theory with practice. Furthermore, in Chapter 9, Robert Shumer presents three critical points for future service-learning activists to keep in mind: (1) the goal of service-learning is community engagement, (2) it is critical to heed the advice of educational reformists, and (3) "the strength of service-learning has been always rooted in its own community, students" (Shumer, 2017, p. 139). Though these three pieces of advice are not directly mentioned in each chapter, the importance of each is implied throughout the entire book. Serving as a magnificently crafted capstone, Chapter 12 describes the commonalities among all of the chapters while, more importantly, listing six essential recommendations for the next generation of individuals involved in service-learning. In short, these items consist of: (1) new service-learning leaders and mentors will rise, (2) continue to create service-learning environment and opportunities for young people, (3) promote professional development opportunities linked with the field, (4) continue meetings and conferences that promote service-learning best practices, (5) advocate for further research and evaluation of such practices, and (6) address community issues/problems that arise.

Where's the Wisdom in Service-Learning? contributes to the existing literature on servicelearning by synthesizing over four decades of personal experience from disparate scholars while highlighting their unique individual insights on the field's progression. By including the perspectives of several experienced authors, Shumer allows the reader to appreciate and glean from the transformative and widespread impact of an array of service-learning initiatives. Similarly, allowing each author to provide his or her own advice about future practice, as well as including a synopsis of such recommendations in the concluding chapter, helps readers to envision a path toward continued success in their service-learning efforts. Moreover, this volume represents both a reflective pause addressing where the field has been and an informed, clarion call about how to move forward. 


\section{Author Note}

Christopher Adam Ray, Admissions, Western Carolina University.

Correspondence regarding this article should be addressed to Christopher Adam Ray, Assistant Director of Admissions, Western Carolina University, 140 L Cordelia Camp, Cullowhee, NC 28723. Phone: (828) 227-7317. E-mail: caray@email.wcu.edu

\section{References}

Edgerton, R. (1997). Education white paper. Report for the Pew Charitable Trusts Board of Directors. Philadelphia: Pew Charitable Trusts.

Shulman, L. (2002). Making differences: A table of learning. Change: The Magazine of Higher Learning, 34(6), 36-44.

Shumer, R. (2017). Where's the wisdom in service-learning?: My story. In R. Shumer (Ed.), Where's the wisdom in service-learning? (pp. 129-142). Charlotte, NC: Information Age Publishing.

Shumer, R., Stanton, T. K., \& Giles, Jr., D. E. (2017). History and pre-cursors of service-learning theory, development, and research. In R. Shumer (Ed.), Where's the wisdom in servicelearning? (pp. 1-32). Charlotte, NC: Information Age Publishing.

Stanton, T., Giles, D., \& Cruz, N. (1999). Service-learning: A movement's pioneers reflect on its origins, practice, and future. San Francisco: Jossey-Bass. 